\title{
Analisis Determinan Bauran Pemasaran pada Poliklinik Rawat Jalan RSK dr. Rivai Abdullah Palembang
}

\author{
A.Yosef Wempie ${ }^{1}$, Nur Alam Fajar ${ }^{2}$, Haerawati Idris ${ }^{3}$ \\ ${ }^{1,2,3}$ Magister Kesehatan Masyarakat, Universitas Sriwijaya Palembang, Indonesia \\ Email:wempie2017@gmail.com
}

\begin{abstract}
Analysis of Marketing Mix Determinants at Outpatient Polyclinic of RSK. dr. Rivai Abdullah Palembang. Leprosy Hospital of dr. Rivai Abdullah Palembang in the last 3 (three) years found data on visitors who came to the Outpatient Polyclinic showed a downward trend every year since 2015. This study aims to determine the influence of patient perceptions of the marketing mix to the patient's loyalty at Outpatient Polyclinic of Leprosy Hospital of dr. Rivai Abdullah Palembang. The study design used a cross-sectional approach, where the population in this study was outpatients in 2017. Data collection using a questionnaire that had previously been tested for validity in 30 respondents on inpatients of RSK. dr. Rivai Abdullah Palembang, samples were taken accidentally as many as 152 respondents in September - October 2018 that met the inclusion and exclusion criteria at Outpatient Polyclinic of RSK of dr. Rivai Abdullah Palembang. Data analysis used chi-square and multiple logistic regression. The results of the study showed that the 7 variables (product, price, promotion, place, people, process and physical evidence) there were 3 variables that were significant relationship with patient loyalty, namely promotion ( $\mathrm{p}$ value $=0.005, \mathrm{OR}=6.491)$, process $(\mathrm{p}$-value $=0,000, \mathrm{OR}=8,796)$, and physical evidence ( $\mathrm{p}$ value $=0,000, \mathrm{OR}=12)$. While the product ( $\mathrm{p}$-value $=0.335, \mathrm{OR}=4,556)$, price $(\mathrm{p}$-value $=1$, $\mathrm{OR}=0,807)$, place $(\mathrm{p}$-value $=1, \mathrm{OR}=0,815)$, people ( $\mathrm{p}$-value $=1, \mathrm{OR}=0.815$ ) showed there was no significant relationship with patient loyalty. The most dominant variable relationship with outpatient loyalty at Leprosy Hospital of dr. Rivai Abdullah Palembang was a physical evidence variable $(\mathrm{OR}=19,867,95 \%$ CI 4,010 98,429).
\end{abstract}

Keywords: Marketing mix, Patient loyalty

\begin{abstract}
Abstrak: Analisis Determinan Bauran Pemasaran Pada Poliklinik Rawat Jalan RSK dr. Rivai Abdullah Palembang. Rumah Sakit Kusta dr. Rivai Abdullah Palembang dalam kurun waktu 3 (tiga) tahun terakhir diketahui data pengunjung yang datang berobat ke Poliklinik Rawat Jalan menunjukkan terjadinya tren penurunan setiap tahunnya sejak tahun 2015. Penelitian ini bertujuan mengetahui pengaruh persepsi pasien tentang bauran pemasaran terhadap loyalitas pasien pada Poliklinik Rawat Jalan di Rumah Sakit Kusta dr. Rivai Abdullah Palembang. Desain penelitian menggunakan pendekatan cross-sectional, dimana populasi pada penelitian ini pasien rawat jalan di tahun 2017. Pengumpulan data dengan menggunakan kuesioner yang sebelumnya telah dilakukan uji validitas pada 30 responden pada pasien rawat inap RSK. dr. Rivai Abdullah Palembang, sampel yang dilakukan secara accidental sebanyak 152 responden pada bulan September-Oktober 2018 yang memenuhi kriteria inklusi dan eksklusi di Poliklinik rawat Jalan RSK. dr. Rivai Abdullah Palembang. Analisis data menggunakan chi-square dan regresi logistik ganda. Hasil penelitian menunjukan bahwa dari 7 variabel (produk, harga, promosi, tempat, orang, proses dan bukti fisik) ada 3 variabel yang berhubungan signifikan dengan loyalitas pasien yaitu promosi $(p$-value $=0.005, \mathrm{OR}=6,491)$, proses $(p$-value $=0.000, \mathrm{OR}=8,796)$, dan bukti fisik $(p$ value $=0.000, \mathrm{OR}=12)$. Sedangkan produk ( $p$-value $=0.335, \mathrm{OR}=(4,556)$, harga $(p$-value $=1$, $\mathrm{OR}=0,807)$, tempat ( $p$-value $=1, \mathrm{OR}=0,815)$, orang ( $p$-value $=1, \mathrm{OR}=0,815)$ menunjukkan tidak ada hubungan yang signifikan dengan loyalitas pasien. Variabel yang paling dominan berhubungan dengan loyalitas pasien rawat jalan pada Rumah Sakit Kusta dr. Rivai Abdullah Palembang adalah variabel bukti fisik. (OR=19,867, 95\% CI 4,010 98,429).
\end{abstract}

Kata Kunci: Bauran Pemasaran, Loyalitas pasien

\section{PENDAHULUAN}

Rumah Sakit Kusta dr. Rivai Abdullah Palembang merupakan salah satu rumah sakit vertikal khusus kusta kelas A yang telah menerapkan Pola Pengelolaan Keuangan Badan Layanan Umum (PPK BLU) berdasarkan Peraturan Menteri Keuangan Republik Indonesia 
Nomor 3/KMK.05/2010 Tanggal 5 Januari 2010 dan pada tahun 2012 diberikan izin untuk melayani pasien umum seluas-luasnya sesuai dengan Peraturan Menteri Kesehatan Nomor 010 Tahun 2012 tanggal 14 Maret 2012 tentang organisasi dan tata kerja Rumah Sakit Kusta dr. Rivai Abdullah Palembang. Rumah Sakit Kusta dr. Rivai Abdullah Palembang dalam kurun waktu 3 (tiga) tahun terakhir diketahui data pengunjung yang datang berobat ke Poliklinik rawat jalan Rumah Sakit Kusta dr. Rivai Abdullah Palembang menunjukkan terjadinya tren penurunan setiap tahunnya seperti yaitu pada tahun 2015 sebanyak 21.300 pasien, pada tahun 2016 sebanyak 15.640 pasien dan pada tahun 2017 sebanyak 6.324 pasien (Profil Rumah Sakit Kusta dr. Rivai Abdullah Palembang Tahun 2018).

Salah satu indikator kinerja rumah sakit yaitu BOR (Bed Occupancy Rate), data dari sub bagian evaluasi dan pelaporan data yang terdapat pada Profil RSK. dr. Rivai Abdullah Palembang didapatkan data yaitu pada tahun 2015 sebesar $25,56 \%$, tahun 2016 sebesar $22,72 \%$, dan tahun 2017 sebesar 28,08\%. Dilihat dari data tersebut bahwa angka BOR (Bed Occupancy Rate) belum mencapai standar nasional yaitu $60-80 \%$ yang merupakan indikator kinerja penilaian rumah sakit umum/khusus dibawah kementerian Kesehatan Republik Indonesia. Bauran pemasaran (marketing mix) adalah salah satu bentuk strategi pemasaran. Bauran pemasaran yang biasa digunakan perumahsakitan di Indonesia adalah $5 \mathrm{P}$ yaitu: product, place price, people dan promotion. Selain 5P di atas juga bisa ditambahkan process dan physical evidence.

Penerapan strategi bauran pemasaran (marketing mix) yang tepat dan baik tentunya akan mempengaruhi terhadap mutu pelayanan yang diberikan kepada pasien sekaligus merupakan konsumen suatu rumah sakit. Berdasarkan penelitian yang dilakukan Ajeng Tahun 2017 di Instalansi Rawat Jalan RSK. Dr. Sitanala Tanggerang didapatkan bahwa adanya hubungan yang signifikan antara produk (jasa) dengan $p$-value $=0.025$ nilai OR 4,263 , layanan pelanggan terhadap loyalitas pasien dengan $p$ value $=0.002$ sedangkan untuk persepsi bauran pemasaran yang lain tidak menunjukan hubungan yang signifikan seperti promosi, lokasi, orang (SDM), harga, proses, dan bukti fisik.

Berdasarkan uraian diatas maka peneliti tertarik melakukan penelitian analisis determinan bauran pemasaran (marketing mix) pada poliklinik rawat jalan di Rumah Sakit Kusta dr. Rivai Abdullah Palembang. Tujuan penelitian ini adalah mengetahui pengaruh determinan bauran pemasaran terhadap loyalitas pasien pada Poliklinik Rawat Jalan di Rumah Sakit Kusta dr. Rivai Abdullah Palembang.

\section{METODE}

Desain penelitian menggunakan pendekatan cross-sectional, dimana populasi pada penelitian ini adalah pasien rawat jalan di tahun 2017 yang berjumlah 6.324 pasien. Pengumpulan data dengan menggunakan kuesioner yang sebelumnya telah dilakukan uji validitas terhadap 30 responden. Sampel pada penelitian ini berjumlah 152 pasien yang memenuhi kriteria inklusi dan eksklusi dimana teknik pengambilannya dengan menggunakan teknik accidental sampling.

Instrumen pada penelitian ini berupa kuesioner, setiap pertanyaan dalam kuesioner berbentuk Skala Likert. Data hasil penelitian diolah dengan menggunakan sistem pengolahan data komputer dengan menggunakan perangkat lunak (software) komputer. Data yang terkumpul kemudian diolah melalui tahap-tahap antara lain editing, tabulating, scoring, processing, dan cleaning

Analisis data dalam penelitian ini meliputi analisis univariat, analisis bivariat dan analisis multivariat. Analisis univariat dilakukan untuk memperoleh gambaran distribusi frekuensi semua variabel penelitian baik variabel dependen maupun variabel independen. Analisis bivariat menggunakan uji chi-square dengan tingkat kepercayaan $95 \%(\alpha=0.05)$ dan dilakukan untuk mengetahui pengaruh variabel independen terhadap variabel dependen, analisis multivariat yang akan digunakan dalam penelitian ini adalah analisis regresi logistik ganda.

Desain penelitian menggunakan pendekatan cross-sectional, dimana populasi pada penelitian ini adalah pasien rawat jalan di tahun 2017 yang berjumlah 6.324 pasien. Pengumpulan data dengan menggunakan kuesioner yang sebelumnya telah dilakukan uji validitas terhadap 30 responden. Sampel pada penelitian ini berjumlah 152 pasien yang memenuhi kriteria inklusi dan eksklusi dimana teknik pengambilannya dengan menggunakan teknik accidental sampling. 
HASIL

Tabel 1. Distribusi Frekuensi Variabel Dependen dan Variabel Independen

\begin{tabular}{lrr}
\hline \multirow{2}{*}{ Variabel } & \multicolumn{2}{c}{ Sampel } \\
\cline { 2 - 3 } & \multicolumn{1}{c}{ n } & \% \\
\hline Loyalitas Pasien Rawat Jalan & & \\
Loyal & 124 & 81,6 \\
Kurang Loyal & 28 & 18,4 \\
\hline Produk (Product) & & \\
Baik & 150 & 98,7 \\
Kurang Baik & 2 & 1,3 \\
\hline Harga (Price) & 150 & 98,7 \\
Terjangkau & 2 & 1,3 \\
Tidak Terjangkau & & \\
\hline Promosi (Promotion) & 141 & 92,8 \\
Baik & 11 & 7,2 \\
Kurang Baik & & \\
\hline Tempat (Place) & 151 & 99,3 \\
Baik & 1 & 0,7 \\
Kurang Baik & & \\
\hline Orang (People) & 151 & 99,3 \\
Baik & 1 & 0,7 \\
Kurang Baik & & \\
\hline Proses (Process) & 109 & 71,7 \\
Baik & 43 & 28,3 \\
\hline Kurang Baik & & \\
\hline Bukti Fisik & 140 & 92,1 \\
Baik & 12 & 7,9 \\
Kurang Baik & &
\end{tabular}

Dari tabel 1 diketahui bahwa dari 152 responden didapat bahwa responden yang loyal terhadap pelayanan kesehatan di Poliklinik Rawat Jalan RSK. dr. Rivai Abdullah Palembang 63,2\% lebih banyak dari pada responden yang kurang loyal. mayoritas responden mempunyai persepsi baik terhadap produk yaitu sebanyak $98,7 \%$ responden, mayoritas responden mempunyai persepsi terjangkau terhadap harga yaitu sebanyak $98,7 \%$ responden, responden yang mempunyai persepsi baik terhadap promosi (promotion) sebanyak 36,8\% lebih banyak dari pada responden yang mempunyai persepsi kurang baik terhadap promosi (promotion), mayoritas responden $(99,3 \%)$ mempunyai persepsi baik terhadap tempat, pada umumnya $99,3 \%$ responden mempunyai persepsi yang baik terhadap orang/sumber daya manusia, reponden yang mempunyai persepsi baik terhadap proses 2,5 kali lebih banyak dibandingkan dengan responden yang memiliki persepsi kurang baik terhadap proses (process), dan sebagian besar responden $(89 \%)$ memiliki persepsi baik terhadap bukti fisik di Poliklinik Rawat Jalan RSK. dr. Rivai Abdullah Palembang.

\section{Analisis Bivariat}

Uji yang digunakan dalam penelitian ini adalah uji statistik Chi-square dengan $\alpha=0,05$. Jika $p$-value (probabilitas) lebih kecil atau sama dengan $\alpha(0,05)$, berarti menunjukkan bahwa ada hubungan antara variabel bebas (independen) dengan variabel terikat (dependen).

Tabel 2. Hasil Analisis Bivariat

\begin{tabular}{|c|c|c|c|c|c|c|c|c|}
\hline \multirow{3}{*}{ Variabel } & \multicolumn{4}{|c|}{$\begin{array}{c}\text { Loyalitas } \\
\text { Pasien Rawat Jalan } \\
\end{array}$} & \multirow{2}{*}{\multicolumn{2}{|c|}{ Jumlah }} & \multirow{3}{*}{ p value } & \multirow{3}{*}{$\begin{array}{c}\text { OR } \\
95 \% \mathrm{CI}\end{array}$} \\
\hline & \multicolumn{2}{|c|}{ Loyal } & \multicolumn{2}{|c|}{ Kurang Loyal } & & & & \\
\hline & $\mathbf{n}$ & $\%$ & $\mathbf{n}$ & $\%$ & n & $\%$ & & \\
\hline \multicolumn{7}{|l|}{ Produk (product) } & \multirow{3}{*}{0,335} & \multirow{3}{*}{$\begin{array}{r}4,556 \\
0,276-75,134\end{array}$} \\
\hline Baik & 123 & 82 & 27 & 18 & 150 & 100 & & \\
\hline Kurang baik & 1 & 50 & 1 & 50 & 2 & 100 & & \\
\hline \multicolumn{7}{|l|}{ Harga (price) } & \multirow{3}{*}{1} & \\
\hline Terjangkau & 121 & 80,7 & 29 & 19,3 & 150 & 100 & & $\begin{array}{r}0,807 \\
0746,872\end{array}$ \\
\hline Tidak terjangkau & 2 & 100 & 0 & 0 & 2 & 100 & & $0,746-0,872$ \\
\hline \multicolumn{7}{|c|}{ Promosi (promotion) } & \multirow{3}{*}{0,005} & \\
\hline Baik & 119 & 84,4 & 22 & 15,6 & 141 & 100 & & 0,491 \\
\hline Kurang baik & 5 & 45,5 & 6 & 54,5 & 11 & 100 & & 23,150 \\
\hline \multicolumn{7}{|l|}{ Tempat (place) } & \multirow{3}{*}{1} & \\
\hline Baik & 123 & 81,5 & 28 & 18,5 & 151 & 100 & & $\begin{array}{r}0,815 \\
0755 \\
0870\end{array}$ \\
\hline Kurang baik & 1 & 100 & 0 & 0 & 1 & 100 & & $0, / 55-0,8 / 9$ \\
\hline \multicolumn{7}{|l|}{ Orang (people) } & \multirow{3}{*}{1} & \\
\hline Baik & 123 & 81,5 & 28 & 18,5 & 151 & 100 & & 0,015 \\
\hline Kurang baik & 3 & 100 & 0 & 0 & 1 & 100 & & $0,755-0,8 / 9$ \\
\hline \multicolumn{7}{|l|}{ Proses (process) } & \multirow{3}{*}{0,000} & \\
\hline Baik & 100 & 91,7 & 9 & 8,3 & 109 & 100 & & $\begin{array}{r}8,796 \\
3542-21845\end{array}$ \\
\hline Kurang baik & 24 & 55,8 & 19 & 44,2 & 43 & 100 & & $3,542-21,845$ \\
\hline \multicolumn{7}{|c|}{ Bukti Fisik (physical Evidence) } & \multirow{3}{*}{0,000} & \multirow{3}{*}{$\begin{array}{r}12 \\
3,303-43,602\end{array}$} \\
\hline Baik & 120 & 85,7 & 20 & 14,3 & 140 & 100 & & \\
\hline Kurang baik & 4 & 33,3 & 8 & 66,7 & 12 & 100 & & \\
\hline
\end{tabular}


Berdasarkan tabel 2 diketahui bahwa tidak ada hubungan yang signifikan antara produk dengan loyalitas pasien rawat jalan ( $p$ value $=0,335)$, Tidak ada hubungan yang signifikan antara harga dengan loyalitas pasien rawat jalan ( $p$-value $=0,807$ ), ada hubungan yang signifikan antara promosi dengan loyalitas pasien rawat jalan ( $p$-value $=0,005)$, tidak ada hubungan yang signifikan antara tempat dengan loyalitas pasien rawat jalan ( $p$-value $=1)$, tidak ada hubungan yang signifikan antara harga dengan loyalitas pasien rawat jalan ( $p$-value $=1$ ), ada hubungan yang signifikan antara proses dengan loyalitas pasien rawat jalan ( $p$-value $=0,000$ ), ada hubungan yang signifikan antara bukti fisik dengan loyalitas pasien rawat jalan ( $p$ value $=0,000$ ).

\section{Analisis Multivariat}

Analisis multivariat dilakukan untuk mengetahui variabel independen mana yang paling besar pengaruhnya terhadap variabel dependen.

\section{Tabel 3. Hasil Analisis Multivariat}

\begin{tabular}{lccccc}
\hline \multirow{2}{*}{ Variabel } & \multirow{2}{*}{ B } & \multirow{2}{*}{ Sig. } & \multirow{2}{*}{$\boldsymbol{E x p}(\mathbf{B})$} & \multicolumn{2}{c}{$\mathbf{9 5 \%}$ C.I.for } \\
\cline { 5 - 6 } & & & & Exwer & Upper \\
\hline Promosi & 2,099 & 0,014 & 8,155 & 1,539 & 43,220 \\
Proses & 2,441 & 0,000 & 11,486 & 3,842 & 34,340 \\
Bukti & 2,989 & 0,000 & 19,867 & 4,010 & 98,429 \\
fisik & & & & & \\
\hline Constant & $-10,637$ & 0,000 & 0,000 & & \\
\hline
\end{tabular}

Berdasarkan tabel 3 nilai OR tertinggi didapatkan variabel yang paling dominan yang berhubungan dengan loyalitas pasien rawat jalan pada Rumah Sakit Kusta dr. Rivai Abdullah Palembang adalah variabel bukti fisik dengan $\mathrm{OR}=19,867$, artinya responden dengan persepsi baik terhadap proses lebih berpeluang 19,867 kali untuk bersikap loyal dibandingkan dengan responden yang memiliki persepsi proses kurang baik

\section{PEMBAHASAN}

\section{Produk (Product)}

Penelitian ini mendapatkan informasi bahwa tidak ada hubungan antara produk dengan loyalitas pasien Poliklinik Rawat jalan RSK. Dr. Rivai Abdullah Palembang, dengan nilai $P$ value $=0,335$, sebagian besar responden $(95,4 \%)$ menyatakan bahwa dimasa yang akan datang akan selalu menfaatkan pelayanan di RSK dr. Rivai Abdullah Palembang. Hal ini sejalan dengan penelitian yang dilakukan Sembor tahun 2017 di di Unit Rawat Jalan Rumah Sakit Siloam Manado yang menyatakan bahwa tidak adanya hubungan yang signifikan antara produk (jasa) dengan nilai $p$-value $=0,190$ dan nilai OR 1,94 .

Penelitian ini juga didapatkan menginformasikan bahwa responden yang mempunyai persepsi kurang baik hanya 2 responden dan itu juga terbagi menjadi 2 yaitu 50\%-nya bersikap loyal dan 50\% lagi sebaliknya yaitu tidak loyal, sehingga secara umum tidak mempengaruhi loyalitas seseorang untuk datang kembali ke RSK. dr. Rivai Abdullah Palembang.

Berdasarkan teori bahwa persepsi seseorang akan dipengaruhi oleh faktor internal dan eksternal, faktor internal yang dapat mempengaruhi seseorang adalah pengalaman terhadap pemakaian suatu produk, kebutuhan, harapan dan nilai-nilai yang dianut, sedangkan faktor eksternal, yaitu situasi lingkungan, penampilan suatu produk serta sifat-sifat stimulu. (Poernomo, 2009).

Berdasarkan teori dan hasil penelitian juga menyebutkan bahwa walaupun secara kuantitas produk layanan yang tersedia di RSK dr. Rivai Abdullah sudah memenuhi standar, tapi secara kualitas atau mutu pelayanan juga akan mempengaruhi keputusan seseorang datang kembali untuk memanfaatkan pelayanan tersebut dan tentunya akan menjadi marketing yang baik bagi rumah sakit dalam menghadirkan konsumen-konsumen yang lain. Strategi yang harus manajemen rumah sakit dapat lakukan dengan mendatangkan pasien dengan menyediakan produk-produk unggulan yang tidak dimiliki atau minim dimiliki oleh peneyedia fasilitas pelayanan kesehatan yang lain sehingga menjadi daya tarik tersendiri bagi pasien untuk datang dan mendapatkan pelayanan tersebut walaupun dari tempat yang jauh.

Kebijakan-kebikjakan dari manajemen rumah sakit tentang inovasi jenis-jenis produk layanan yang baru tentunya akan mempengaruhi loyalitas pasien yaitu sesuai dengan kebutuhan yang diharapkan pasien sebagai konsumen, ditambah lagi dengan semakin meningkatnya kebutuhan masyarakat terhadap layanan kesehatan yang paripurna, tentunya sebuah rumah sakit harus mempunyai strategi yang tepat dalam melakukan pemasaran produk layanan kesehatan yang ditawarkan.

\section{Harga (Price)}

Pada penelitian ini didapatkan bahwa tidak terdapat hubungan yang signifikan antara harga dengan loyalitas pasien nilai $p$-value $=1$ dan 
$\mathrm{OR}=0,807$. Penelitian ini sejalan dengan penelitian yang dilakukan oleh Kusumo (2015) pada pasien Rawat Inap RS PKU Muhammadiyah Bantul bahwa tidak ada hubungan yang signifikan antara harga dengan loyalitas pasien. Hal ini berarti bahwa harga bukan merupakan suatu permasalahan bagi umumnya pasien rawat jalan untuk datang kembali berkunjung. Walaupun sebagian besar responden menyatakan bahwa tarif layanan yang ada dipoliklinik rawat jalan terjangkau, tapi ada sebanyak $44,1 \%$ responden menyatakan tidak setuju dengan pernyataan bahwa mereka tidak akan pindah ke rumah sakit lain walaupun tarif di RSK. dr. Rivai Abdullah Palembang ini dinaikkan.

Hal ini mengindikasikan bahwa masih ada responden yang merasa bahwa apa yang mereka harapkan dengan pelayanan dan tarif sekarang belum sesuai/terpenuhi apalagi dengan dinaikkannya tarif, hal ini didukung juga dengan adanya sebanyak $8,6 \%$ responden menyatakan bahwa pelayanan yang diberikan belum sesuai dengan tarif yang disediakan. Peneliti melihat dan menilai bahwa permasalahan terjadinya penurunan kunjungan pasien rawat jalan disebabkan oleh faktor eksternal yang salah satunya adalah rujukan berjenjang JKN. Untuk faktor internal seperti pola tarif perlu dilakukan penyesuaian tarif yang kompetitif.

Dalam strategi pemasaran, pendekatan segmentasi yang mendukung gagasan bahwa kelompok konsumen yang berbeda akan menempatkan nilai yang berbeda pada layanan, dan karena itu memerlukan strategi penetapan harga/tarif yang berbeda pula (Ahmad et al, 2013). Seperti halnya dengan adanya perusahaanperusahaan yang ada disekitar wilayah binaan rumah sakit, dapat dilakukan Perjanjian Kerjasama (PKS) dengan diterapkannya daftar tarif khusus seperti adanya harga khusus/diskon untuk momen-momen tertentu sehingga menjadi daya tarik tersendiri bagi konsumen untuk dapat berkunjung dan menjadi loyal terhadap layanan yang dberikan oleh Rumah Sakit Kusta dr. Rivai Abdullah Palembang.

\section{Promosi (Promotion)}

Berdasarkan hasil analisis data diketahui bahwa pada penelitian ini terdapat hubungan yang signifikan antara promosi dengan loyalitas pasien nilai $p$-value $=0,005$ dan $\mathrm{OR}=6,491$. Penelitian ini sejalan dengan penelitian yang dilakukan Yulyandhika (2013), bahwa ada hubungan antara bauran promosi $(p=0,000)$ dengan loyalitas pasien di Rawat Inap RSUD Syekh Yusuf Kabupaten Gowa Tahun 2013.

Berdasarkan penelitian ini juga didapatkan informasi bahwa pada umumnya dari $93 \%$ responden menyatakan bahwa adanya ketersediaan informasi mengenai RSK. dr. Rivai Abdullah Palembang. Ini berarti bahwa rumah sakit telah melaksanakan promosi seperti adanya informasi mengenai profil rumah sakit, kegiatan, survey kepuasan di website, leaflet, brosur, papan nama, jalinan kerja sama (PKS) dengan stakeholder terkait. Selain dengan mengunakan brosur, leaflet, promosi juga dapat dikembangkan melalui seminar-seminar, pelatihan-pelatihan yang di informasikan kepada masyarakat dan stakeholder melalui media elektronik, media masa, media sosial dan media lainnya

Berdasarkan data yang didapat, bahwa sebanyak $29,6 \%$ responden yang menyatakan bahwa RSK. dr. Rivai Abdullah Palembang belum melakukan penyuluhan kesehatan secara berkala kepada pasien. Ini berarti bahwa boleh jadi pelaksanaan penyuluhan yang ada di RSK. dr. Rivai Abdullah Palembang selama ini belum tersosialisasi dengan baik kepada pasien/keluarga atau sebaliknya bahwa pelaksanaanya belum dapat terlaksanan maksimal dan yang perlu dijadikan perhatian bahwa harus adanya kebijakan dari pihak manajemen rumah sakit dalam hal upaya peningkatan baik secara kuantitas maupun kualitas pelaksanaan penyuluhan kesehatan secara berkala kepada pasien baik di rawat jalan maupun rawat inap.

Tingginya frekuensi promosi serta berbagai jenis media yang digunakan memungkinkan dapat berdampak lebih untuk menjangkau konsumen. Selanjutnya sebuah penelitian mengklaim bahwa promosi merupakan faktor penting dalam pemasaran yang ditujukan untuk menjangkau pasien potensial dan mempengaruhi keputusan pasien lama untuk tetap mempertahankan pilihan mereka terhadap layanan yang diberikan. Seperti halnya dalam harga, bentuk diskon/potongan harga bagi pasien umum untuk stakeholder yang telah menjalin kerjasama, acara tertentu juga merupakan bentuk strategi promosi bagi rumah sakit dalam memenuhi harapan pasien dengan tanpa mengurangi kuantitas dan kualitas pelayanan sehingga dapat mendatangkan kunjungan pasien umum tanpa harus hanya bergantung pada pasien yang memiliki Jaminan Kesehatan Nasional (JKN) yang baru dapat melakukan kunjungan sesuai alur jenjang rujukan.

Dari penelitian ini juga didapatkan informasi bahwa responden masih mengalami kesulitan dalam menyampaikan keluhan 
mengenai pelayanan yang ada di poliklinik Rawat Jalan RSK. dr. Rivai Abdullah Palembang, hal ini terbukti dengan adanya $14,5 \%$ responden masih sulit menyampaikan keluhan bila ada pelayanan di RSK. dr. Rivai Abdullah Palembang yang tidak memuaskan. Hendaknya pihak manajemen rumah sakit perlu mengevaluasi tata cara penyampaian keluhan atau komplain yang telah dilaksanakan selama ini, yang mungkin pelaksanaannya perlu diubah atau ditambah metodenya agar dapat memberikan masukan sesuai harapan konsumen sehingga loyalitas pasien untuk datang ke rumah sakit dapat meningkat.

\section{Tempat (Place)}

Berdasarkan analisis data dengan chi square diketahui bahwa pada penelitian ini tidak terdapat hubungan yang signifikan antara bauran pemasaran tempat dengan loyalitas pasien nilai $p$ value $=1$ dan $\mathrm{OR}=0,815$. Penelitian ini sejalan dengan penelitian yang dilakukan oleh Poernomo di Poliklinik Rawat Jalan Rumah Sakit Baptis Kediri tahun 2009, menyatakan bahwa tidak ada hubungan antara persepsi pasien tentang bauran pemasaran tempat dengan loyalitas pasien dengan nilai $\mathrm{p}=0,062$. Berbeda halnya dengan penelitian yang dilakukan Sembor dkk (2015) bahwa terdapat hubungan yang signifikan antara tempat dengan loyalitas pasien rawat jalan di Rumah Sakit Siloam Manado.

Berdasarkan teori bahwa bauran pemasaran tempat di rumah sakit merupakan upaya yang dilakukan rumah sakit agar layanan yang diberikan dapat dijangkau oleh pasien sebagai sasaran pemasaran. Dalam memilih tempat dan lokasi memerlukan pertimbangan yang seksama terhadap prinsip-prinsip tempat, yaitu ketersediaan jenis-jenis layanan, keadilan tempat layanan kesehatan, kesetaraan bagi mereka yang benar-benar membutuhkan kenyamanan dan kemudahan. atau penempatan yang nyaman serta menyenangkan pada saat menerima layanan kesehatan.

Berdasarkan penelitian didapatkan informasi bahwa akses dan transportasi menuju ke RSK dr. Rivai Abdullah Palembang bukan merupakan suatu kendala bagi pasien dalam proses mendapatkan pelayanan kesehatan di rumah sakit, hal ini terjadi besar kemungkinan bahwa pasien yang datang berobat ke poliklinik rawat jalan adalah pasien yang tinggal disekitar rumah sakit atau pasien lama yang sudah merasa cocok dengan pelayanan kesehatan di RSK. dr. Rivai Abdullah palembang. Namun yang perlu dipertimbangkan adalah dimaksimalkannya akses bagi masyarakat yang tinggal didaerah perairan, mengingat akses menuju ke rumah sakit juga dapat dilalui dengan akses sungai di berada dibelakang rumah sakit. Untuk Fasilitas penunjang dan kondisi lingkungan di RSK dr. Rivai Abdullah Palembang juga mendapatkan respon yang positif dari responden.

\section{Orang (People)}

Berdasarkan analisis data diketahui bahwa pada penelitian ini tidak terdapat hubungan yang signifikan antara orang (people) dengan loyalitas pasien nilai $p$-value $=1$ dan $\mathrm{OR}=0,815$. Hal ini dapat dilihat pada data bahwa tidak ada responden yang memiliki persepsi kurang baik yang bersikap kurang loyal pada poliklinik rawat jalan RSK. dr. Rivai Abdullah Palembang. Penelitian ini sejalan dengan penelitian yang dilakukan Sembor (2015) bahwa ada hubungan antara bauran pemasaran orang dengan loyalitas pasien di Unit Rawat Jalan Rumah Sakit Siloam Manado, sedangkan penelitian yang dilakukan Napirah (2016) pada Unit Perawatan Intensif Rumah sakit Anutapura Palu Tahun 2016, bahwa tidak ditemukannya hubungan antara orang/petugas dengan loyalitas pasien.

Penelitian ini didapatkan juga informasi bahwa persepsi pasien terhadap orang/petugas poliklinik RSK dr. Rivai Abdullah Palembang sudah baik, dibuktikan dengan mayoritas responden menyatakan petugas dapat berkomunikasi baik, bersikap informatif, berpenampilan rapi, serta ramah dan sopan selama berinteraksi memberikan pelayanan kepada pasien. Dalam teori menyatakan bahwa petugas merupakan suatu unsur yang vital dalam keberhasilan pemasaran rumah sakit, karena dengan perilaku efektif petugas dapat menjadi daya tarik dari pelanggan. Dalam konsep pemasaran terintegrasi bahwa peran pemasaran dapat dilakukan oleh semua petugas di setiap bagian.

Penelitian ini juga mendapatkan informasi bahwa ada sebanyak 7\% responden menyatakan bahwa petugas dalam memberikan pelayanan masih kurang ramah dan sopan. Hal ini perlu ditindaklanjuti oleh pihak manajemen karena citra petugas dalam memberikan pelayanan dapat berdampak dengan kenyaman pasien dalam proses mendapatkan layanan kesehatan yang tentunya akan mempengaruhi loyalitas responden untuk dapat datang kembali berkunjung ke Poliklinik Rawat Jalan Rumah Sakit Kusta dr. Rivai Abdullah Palembang. 


\section{Proses (Process)}

Berdasarkan penelitian ini, didapatkan informasi bahwa ada hubungan yang signifikan antara proses dengan loyalitas pasien rawat jalan di Poliklinik Rawat Jalan RSK. dr. Rivai Abdullah Palembang $(p=0,000)$. Penelitian ini sejalan dengan penelitian sebelumnya yang dilakukan oleh Amelia R dkk, 2013 bahwa ada hubungan antara persepsi pasien tentang bauran pemasaran proses dengan loyalitas pasien $(p=0.001$, Exp. $\mathrm{B}=12,103)$ di Rumah Sakit Universitas Hasanuddin Makassar dan penelitian ini tidak sejalan dengan penelitian yang dilakukan oleh Napirah di Unit Rawat Intensif Rumah Sakit Umum Anutapura Palu pada tahun 2016 bahwa tidak ada hubungan yang signifikan antara proses dengan loyalitas pasien.

Dalam penelitian ini didapatkan informasi bahwa mayoritas responden (98\%) menyatakan bahwa alur pelayan mudah dan tidak membingungkan pasien, namun walaupun demikian perlu menjadi perhatian juga bahwa ketepatan waktu dokter dalam melakukan pemeriksaan perlu ditingkatkan lagi karena ada sebanyak $21,7 \%$ responden menyatakan bahwa masih kurangnya ketepatan waktu dokter dalam melakukan pemeriksaan, hal ini mengindikasikan bahwa respon time yang ada sekarang masih terbilang perlu diperbaiki dan ditingkatkan karena dengan pemeriksaan tepat waktu, efektif dan efisien dapat memberikan kenyaman dan kepuasan pasien bagi pasien yang merupakan menjadi marketing yang baik bagi rumah sakit.

Dari penelitian ini juga didapatkan informasi bahwa ada sebanyak $13,2 \%$ responden menyatakan bahwa pasien tidak langsung dilayani petugas setelah mendapatkan nomor antrian. Ini artinya bahwa dalam proses antrian yang lama akan dapat memberikan kesan negatif bagi citra pelayanan rumah sakit. Begitu juga dengan proses pelayanan di farmasi bahwa masih ada sebanyak $7,9 \%$ responden menilai waktu tunggunya masih cukup lama. Proses layanan merupakan serangkaian prosedur, mekanisme rutin dimana sebuah layanan sampai dengan konsumen.

Proses didistribusikan melalui aliran kegiatan, sederhana, kompleks, dan terstandarkan. Keberhasilan pemasaran layanan jasa rumah sakit juga sangat tergantung dengan adanya proses selama penyampaian jasa kepada pasien/keluarga.

Proses pelayanan telah disesuaikan dengan standar prosedur namun yang menjadi catatan penting bagi rumah sakit adalah bagaimana memberikan alur pelayanan yang mudah, cepat dan tepat sehingga kenyamanan pasien dalam proses pengobatan dapat memberikan kepuasan tersendiri bagi pasien, karena proses adalah faktor penting dalam pemasaran layanan rumah sakit, dimana konsumen akan lebih sering menemui sistem administrasi sebagai bagian dari proses layanan itu sendiri. Sebagai tambahan, keputusan dalam manajemen proses juga berpengaruh signifikan untuk menentukan keberhasilan pemasaran rumah sakit.

\section{Bukti Fisik (Physical Evidence)}

Berdasarkan hasil analisis dengan menggunakan chi-square didapatkan bahwa ada hubungan yang signifikan antara bukti fisik dengan loyalitas pasien rawat jalan RSK. dr. Rivai Abdullah Palembang dengan nilai $p=0,000$. Penelitian ini sejalan dengan penelitian yang dilakukan Kusumo \& Susanto terhadap pasien rawat inap RS PKU Muhammadiyah Bantul tahun 2015. Bukti fisik adalah salah satu yang dapat mempengaruhi keputusan konsumen untuk membeli dan memanfaatkan kembali produk yang ditawarkan oleh penyedia jasa. Studi mengatakan bahwa bukti fisik rumah sakit sebagai penyedia layanan kesehatan harus mempertimbangkan penampilan interior dan eksterior serta kinerja mereka yang berinteraksi langsung dengan konsumen (pasien).

Bukti fisik (physical evidence) merupakan lingkungan fisik tempat jasa dibuat dan dapat langsung berinteraksi dengan konsumen antara lain adalah desain interior dan eksterior, saran dan prasarana, suasana lingkungan, kebersihan dan lain-lain. Bukti fisik yang dimiliki oleh rumah sakit adalah sebagai nilai tambah bagi konsumen yang berupa kenyamanan dan kebersihan di lingkungan sekitar tempat pelayanan jasa (Alfianti, 2016).

Sebagian besar responden menyatakan setuju dengan desain, sarana prasarana, suasana lingkungan, kenyamanan ruangan, dan kebersihan RSK. dr. Rivai Abdullah Palembang, hal ini artinya memberikan gambaran bahwa secara umum penampilan fisik Poliklinik Rawat Jalan RSK. dr. Rivai Abdullah Palembang telah dinilai baik oleh responden untuk memberikan rasa aman, nyaman dan kepuasan bagi pasien selama berobat sehingga untuk kedepannya agar dapat ditingkatkan lagi perawatan dan perbaikan secara berkala serta berkelanjutan dan bila perlu adanya penambahan gedung-gedung baru untuk mendukung program pelayanan yang lebih baik kedepannya yang artinya bahwa dengan penampilan fisik yang lebih baik tentunya akan berdampak meningkatnya loyalitas pasien terhadap RSK. dr. Rivai Abdullah Palembang. 


\section{SIMPULAN}

Hasil penelitian didapatkan bahwa terdapat hubungan yang signifikan antara promosi, proses dan bukti fisik dengan loyalitas pasien rawat jalan di Poliklinik Rawat Jalan

\section{DAFTAR PUSTAKA}

Ahmad, AMK, Al-Qarni, A,Alsharqi, OZ, \& Qalai, D, A. (2013). The impact of marketing mix strategy on hospitals performance measured by patient satisfaction: an empirical investigation on Jeddah private sector hospital senior managers perspective. International Journal of Marketing Studies, 5 (6): 210.

Alfianti R,K, Karimuna, R,S, \& Rasma. (2016). Hubungan Bauran Pemasaran (Marketing Mix) Dengan Keputusan Pasien Rawat Inap Memilih Layanan Kesehatan di Rumah Sakit Umum Bahteramas Provinsi Sulawesi Tenggara Tahun 2016. Jurnal Ilmiah Mahasiswa Kesehatan Masyarakat, Vol. 2, No.5. ISSN 250-731x.

Amelia, R, Hamzah, A, Syafar, M. (2013). Pengaruh Bauran Pemasaran Terhadap Loyalitas Pasien Rawat Jalan Di Rumah Sakit Universitas Hasanuddin Makassar 2013. Jurnal AKK, Vol 3 No 1.

Kementerian Keuangan. (2010). Peraturan Menteri Keuangan Republik Indonesia Nomor 3/KMK.05/2010 tanggal 5 Januari 2010 tentang pengolahan kelebihan/kekurangan kas pemerintah.

Kementerian Kesehatan. (2010). Peraturan Menteri Kesehatan Nomor 010 Tahun 2012 tanggal 14 Maret 2012 tentang organisasi dan tata kerja Rumah Sakit Kusta dr. Rivai Abdullah Palembang.
RSK. dr. Rivai Abdullah Palembang. Hasil analisis multivariat menunjukan bahwa variabel yang paling dominan berhubungan dengan loyalitas pasien rawat jalan pada Rumah Sakit Kusta dr. Rivai Abdullah Palembang adalah variabel Bukti Fisik (OR=19,867).

Kusumo, P.M, Susanto. (2015). Pengaruh Faktor Bauran Pemasaran terhadap Loyalitas Pasien Rawat Inap RS PKU Muhammadiyah Bantul. Jurnal Kedokteran dan Kesehatan, vol.12, No.1.

Napirah, R, M, Rau, J, M, \& Hadijah. (2016). The Relationship Between Marketing Mix And Patient Loyalty In Intensive Care Unit, Anutapura Public Hospital Palu. Public Health of Indonesia-YCAB Publisher, Volume 2, Issue 3, July-September 2016.

Poernomo, DISH. (2009). Analisis Pengaruh Persepsi Pasien Tentang Bauran Pemasaran Terhadap Loyalitas Pasien di Poliklinik Rawat Jalan RS Baptis Kediri. (Tesis, Program Pascasarjana, Universitas Diponegoro).

Rumah Sakit Kusta dr. Rivai Abdullah Palembang. (2018). Profil Rumah Sakit Kusta dr. Rivai Abdullah Palembang Tahun 2018. Palembang.

Sembor, P. E., Posangi, J., \& Kaunang, W. P. (2015). Hubungan antara persepsi pasien umum tentang bauran pemasaran jasa dengan loyalitas pasien di unit rawat jalan Rumah Sakit Siloam Manado. Tumou Tou, 1(1).

Yulyandhika, A, Indar, \& Arifin, A. (2013). Hubungan Antara Bauran Pemasaran dengan Loyalitas Pasien di Rawat Inap RSUD Syekh Yusuf. 10(2), 117-123. 